\title{
Experimental investigation on interlocking concrete block for masonry wall of non-engineered earthquake resistant buildings
}

\author{
Mochamad Teguh ${ }^{1, *}$, Furqon Widi Rivai ${ }^{2}$, Novi Rahmyanti ${ }^{1}$, and Erik Wahyu Pradana ${ }^{3}$ \\ ${ }^{1}$ Department of Civil Engineering and Disaster Risk Management, Islamic University of Indonesia, Yogyakarta, Indonesia. \\ ${ }^{2}$ Master Program, Department of Civil and Environmental Engineering, Gadjah Mada University, Yogyakarta, Indonesia. \\ ${ }^{3}$ Department of Civil Engineering, Sebelas Maret University, Surakarta, Indonesia.
}

\begin{abstract}
Most of the seismic damage of existing traditional buildings is due to the absence of practical beam and column structures as the main reinforcement of the building. While a masonry wall as a structural component is commonly negligible due to their relatively low strength in contributing to the frame structure. As a result, when the earthquake struck, the building collapsed, and the ruins of building elements hit the occupants seriously and caused many deaths. This paper presents the results of preliminary research on the experimental investigation of interlocking concrete block for the masonry wall applied to non-engineered earthquake-resistant buildings. The interlocking between concrete blocks is expected to contribute to the strength of the masonry wall in resisting the loads, either in-plane or out-of-plane directions. The novelty of this type of concrete block lies in the uniqueness of the interlocking shape, making it effective in withstanding the earthquake load. This research focuses on the testing of interlocking concrete block units in withstanding loads in the direction and perpendicular to the field and equipped with testing the compressive strength of the wall and diagonal shear strength. The results produce interlocking models of concrete block contribute to better strength than ordinary clay bricks for the masonry wall.
\end{abstract}

\section{Introduction}

Natural disasters with their diversity are quite common phenomena in all regions of Indonesia. This phenomenon is due to geographical, geological, and conditions of Indonesian's relief. Geologically, Indonesia is also located on three main plates, namely Indo-Australia, Eurasia, and the Pacific [1]. The earthquakes that occurred in the past few years indicate that masonry walls without reinforcement and reinforced concrete frames do not have sufficient strength to withstand earthquake loads and cause very high human and economic losses [2]. This condition encourages technicians to develop and promote innovation and technology in alternative building materials $[2,3]$. This building material engineering is primarily intended to improve the seismic performance of building structures by utilizing simple technology, which does not require a high level of construction skills and is economically feasible. Building technology that is often used in Indonesia is strongly influenced by the availability of local materials and local masons. To build nonengineered traditional houses, local building materials, such as bricks, stones, mud, wood, are commonly used [4$6]$.

The need to increase the application of innovation and technology in building materials is very high for disaster risk reduction (DRR) in line with the earthquake intensity recently increases. The results of the innovation and technology of building material materials are oriented towards making masonry walls in non-engineered earthquake-resistant houses.

In reality, the building designer often ignores the contribution of masonry walls as a bracing system in the moment-resisting frame structure, and the masonry wall is considered as a non-structural element that is weak in resisting force [7]. According to Teguh [8], the effect of the strength and stiffness of a brick wall is often not taken into account in the structural analysis due to the wall function is considered as a non-structural component in Indonesian standard (SNI 2847-2013) [9]. In practice, the masonry wall contributes strength in withstanding loads both in the direction of the wall (in-plane direction) and in the perpendicular to the wall (out-of-plane direction), although its contribution is not too significant [7]. The masonry wall contributes to the frame system when it is supported by the quality of the building materials, the installation method, the shape of the brick/concrete block unit, and the skills of the builder.

Previous researches on in-plane seismic behaviour and strengthening techniques of masonry walls were extensively investigated [10-12, 26]; however, the research on out-of-plane masonry walls was still limited [24]. This research focuses on the innovation of interlocking-models on concrete blocks to provide the wall strength, which results from interlocking capabilities and the compressive strength of the concrete block. The novelty of interlocking concrete block in this research is the ability to resist lateral forces in-plane and out-of-plane

\footnotetext{
* Corresponding author: $\underline{\text { m.teguh@uii.ac.id }}$
} 
directions to the wall greater than ordinary brick or concrete block. Some other advantages are the ability of the interlocking concrete block to withstand lateral forces, which is strongly influenced by the quality of the mortar, precision in installation, and builder skills.

\section{Material}

The forming wall materials used in this study were concrete blocks, glass powder for mortar mixtures, and concrete.

\subsection{Typical of interlocking Concrete block}
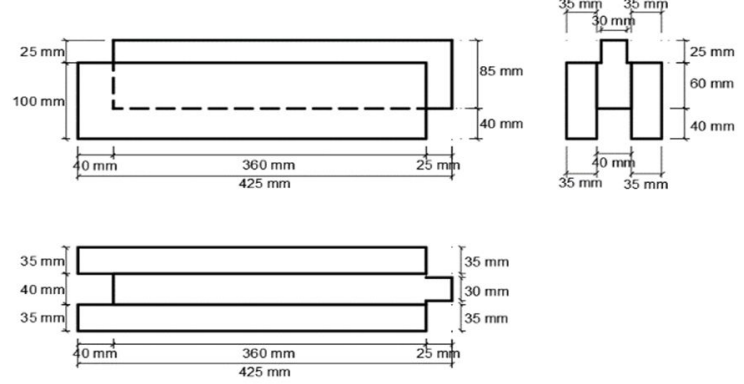

Fig. 1. The dimension of an interlocking concrete block.

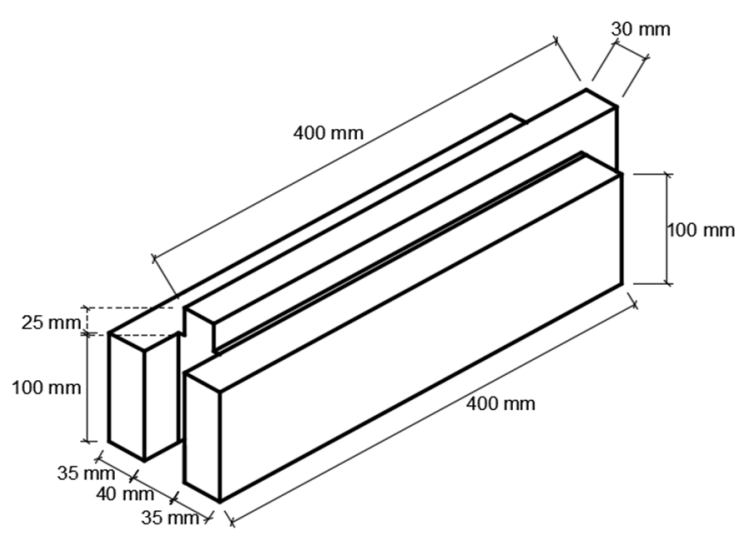

Fig. 2. The perspective of an interlocking concrete block.

The shape of the concrete block in this study was differently made from conventional concrete blocks [3- 4, 19, 29-30]. In general, the traditional concrete block does not have a prominent part on one or the other sides. In this study, an interlocking concrete block was made of ordinary concrete blocks having prominence on the sides. This concrete block has a complicated hook model producing a better interlocking system in an attempt to resist earthquake loads.

This research is intended to innovate an interlocking connection between one concrete block and the other so that the concrete block contributes to an interlocking system. When concrete block units are mounted on a masonry wall, they have the nature of locking each other. The new innovative masonry wall, then, has greater strength in resisting external forces, such as shear forces due to earthquakes. The proposed innovation in this research lies in the models of the hook. In a previous study
[3], the hook height was $3.5 \mathrm{~cm}$, while in this study, the hook was shortened to $2.5 \mathrm{~cm}$. Shortened hooks aim to facilitate the process of making and installing concrete blocks in the masonry walls more easily, as shown in Figs. 1 and 2.

\subsection{Material Composition}

A unique dimension of the concrete block used in this research is $100 \times 400 \times 100(\mathrm{~mm})$. For the walls with a thickness of $100 \mathrm{~mm}$, the cement-sand ratio for a masonry wall can be used with a composition of $1: 8$. when it comes to a higher compressive strength of the wall, the composition ratio can be made with 1:6 or lower. Referring to Teguh [3], the composition of the cementsand for the concrete block used in this research was 1:8 producing sufficient compressive strength, but it still fulfilled the A class criteria of the Indonesia National Standard (SNI 03-6825-2002). The composition ratio is based on a volume unit between Portland cement and sand. In other words, when the higher proportion of sand to cement, then inevitably, it produces a lower of compressive strength.

On this basis, the composition of mortar in this research adopts a previous study of mortar innovation with glass powder mixtures [14-17]. According to Sutrisno [13], substituting 5\% sand with glass powder in mortar mixes can increase up to $23.75 \%$ on average of the compressive strength. In this case, an abrasion machine is used for crushing waste bottles to produce the glass powder. Then the rough glass powder is filtered with a number 200 sieve to produce fine particles, and then the glass powder is then heated to a temperature of $700{ }^{\circ} \mathrm{C}$. Therefore in this research used mortar mixture with glass powder as an innovation material [18]. Two different mortar compositions utilized in this research were 1:4 and 1:5 with and without $5 \%$ of glass powder added as a fine aggregate replacement, and used water-cement ratios of 0.5 and 0.75 , respectively.

\section{Wall Construction Method}

Post-earthquake evidence on residential houses showed that the number of conventional houses was severely damaged due to the performance of unreinforced masonry wall and non-ductile Reinforced Concrete (RC) frame structure insufficiently resisted the seismic loads [7, 22]. This evidence encourages the development and promotion of building material as well as building technology for future works [2].

Material innovations proposed in this research emphasize on enhancement of masonry wall performance utilizing technologies, which require a lower-level of construction skills and economically feasible.

In recent years, there are two common types of masonry wall construction methods, i.e., confined masonry and RC frame infill masonry [7]. In this case, the ASTM E519-02-2002 [21] is adopted in the standard of testing for reinforced and unreinforced interlocking concrete blocks in a masonry wall system. There are two ways to install interlocking concrete block wall, i.e., 
confined masonry and RC frame infill masonry, as shown in Fig. 3 and Fig. 4, referring to Teguh [7].

In connection with the wall construction method, the concrete block installation in a wall using the confined masonry method contributes higher strength, stiffness, and ductility than the RC frame infill masonry method in withstanding cyclic loads [8]. It should be emphasized that both construction methods provide different structural behavior and their impact on in-plane shear failure and out-of-plane wall damage [24]. The masonry wall dimension of interlocking concrete block was 500x500x110 (mm), according to the European Standard EN 1996-6.

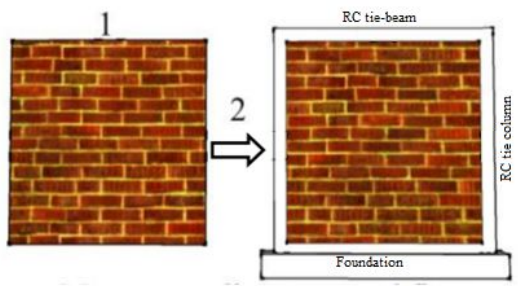

Fig. 3. The construction method of a confined masonry wall.

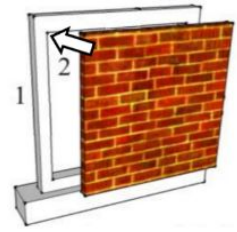

Fig. 4. The construction method of the RC frame infill masonry wall.

\section{Experimental Setup}

The initial test carried out in this study is a diagonal shear test on the walls of an interlocking concrete block. The procedure for the diagonal shear test was based on the ASTM E519-02-2002 guidelines [21]. Fig. 5 presents an experimental setup for the specimen.

The typical wall specimen has a dimension of $1.2 \times 1.2$ (m), and it is set up to rotate by 45 degrees, then at one end of the wall is applied a vertical load. In addition to the diagonal shear test as the initial test, other material characteristic tests of the interlocking concrete block were conducted to examine the compressive strengths of mortar and concrete block, as well as the modulus of elasticity.

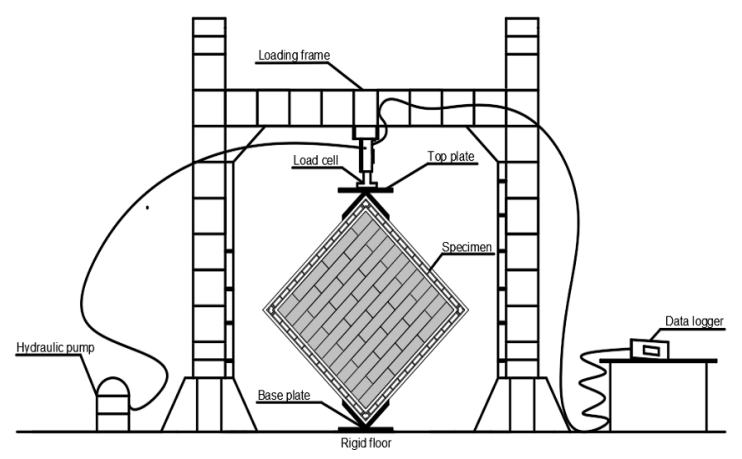

Fig. 5. Experimental setup for the diagonal shear tests.

\section{Results and Discussion}

\subsection{Aggregate Properties}

Aggregate properties for the concrete block and mortar used in this research are essentially examined to determine the quality of the material, whether it meets specifications or not. This material is supplied from the Kulonprogo River, which is located in the western of Yogyakarta town.

Based on the test results of aggregate properties, it can be summarized as follows. Fine and coarse aggregates of density are in the specification in a range of 2.5-2.7. The bulk and solid mass are inclusive of the specification in a variety of 1.2-1.6. Fine-grain modulus aggregate is in a range of 1.5-3.8 and classifies as slightly rough sand. Coarse aggregates are inside the criteria of 5.0-8.0 with a maximum grain size of $40 \mathrm{~mm}$. Percentage of fine and coarse aggregates are specified in the clay fine aggregate with a maximum of $5 \%$, whereas for a coarse aggregate maximum of $1 \%$. The complete results are summarized in Table 1.

Table 1. A summary of the test for aggregate properties.

\begin{tabular}{|c|l|c|c|c|}
\hline No & $\begin{array}{l}\text { Experimental } \\
\text { testing }\end{array}$ & $\begin{array}{c}\text { Fine } \\
\text { aggregate }\end{array}$ & $\begin{array}{c}\text { Coarse } \\
\text { aggregate }\end{array}$ & $\begin{array}{c}\text { Spec. } \\
\text { range }\end{array}$ \\
\hline 1 & $\begin{array}{l}\text { Specific gravity } \\
(\mathrm{SSD})\left(\mathrm{gr} / \mathrm{cm}^{3}\right)\end{array}$ & 2.632 & 2.677 & $2.5-2.7$ \\
\hline 2 & $\begin{array}{l}\text { Bulk density } \\
\left(\mathrm{gr} / \mathrm{cm}^{3}\right)\end{array}$ & 1.284 & 1.265 & $1.2-1.6$ \\
\hline 3 & $\begin{array}{l}\text { Solid density } \\
\left(\mathrm{gr}_{\mathrm{cm}}\right)^{3}\end{array}$ & 1.586 & 1.505 & $1.5-3.8$ \\
\hline 4 & $\begin{array}{l}\text { Fineness } \\
\text { modulus }\end{array}$ & 2.583 & 7.331 & $5.0-8.0$ \\
\hline 5 & $\begin{array}{l}\text { Clay } \\
\text { percentage (\%) }\end{array}$ & 1.300 & 0.750 & $5.0-1.0$ \\
\hline
\end{tabular}

\subsection{Compressive Strength of Mortar}

Mortar in this research is functioned as an adhesive between the concrete block. Therefore, the experimental test of mortar compressive strength is required to determine the quality of the mortar used. Two different unit volumes of the mortar composition, i.e., 1:4 and 1:5, were conducted tests. The comparative test results between the ordinary mortar and mortar with glass powder substitution are illustrated in Fig. 6.

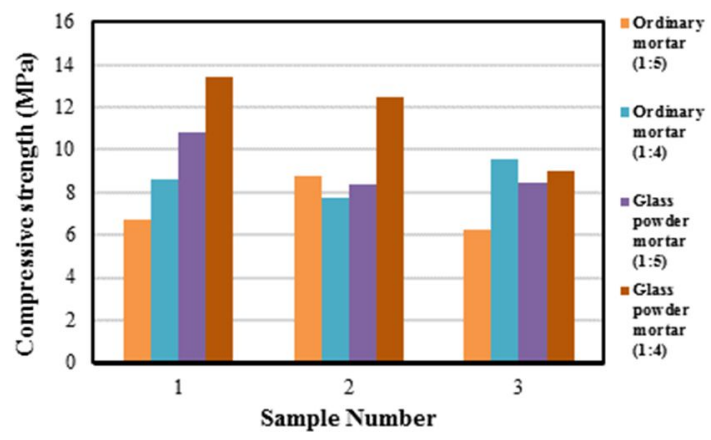

Fig. 6. A variety of mortar compressive strengths. 
The test result of an ordinary mortar with a ratio of 1:5 produces the average compressive strength of $7.24 \mathrm{MPa}$, whereas another ratio of 1:4 provides higher average compressive strength of $8.64 \mathrm{MPa}$. Unlike the mortar admixture substituted with glass powder, both proportions contribute significant compressive strengths of 9.21 and $11.62 \mathrm{MPa}$, respectively.

In general, the results of this test indicate that adding the glass powder into a certain proportion can significantly increase the compressive strength of mortar, but the addition of glass powder has its optimum limit, as suggested in the previous research [18]. The increase in compressive strength of the mortar over $26 \%$ is more dependent on the composition of the Portland cement mixture, sand, and the addition of glass powder, as well as the ratio of water and cement.

\subsection{Diagonal Shear Stress and Ductility Capacity}

Referring to the experimental setup in the diagonal shear test of the wall specimen as previously described, the test was carried out by applying a gradual load to the specimen. The load was applied vertically in the upper and lower corners of the specimen and gradually increased to achieve the maximum load. The wall started to crack as the load, and vertical deflection increased until the collapse occurred. All data were recorded and analyzed to define the value of the diagonal shear strength based on the ASTM formula of E519-02-2002 [21]. This standard is commonly used to test the diagonal shear strength of ordinary masonry walls (without confined with the RC practical beam and column as a wall frame). Due to the unavailability of a similar standard of the Indonesian National Standard (SNI) at the moment, this method is relevant and adopted in this study for conducting tests on three types of masonry walls that are the same material but different construction methods. In addition to the use of E519-02-2002 ASTM standard, Mahmood and Ingham [23] also investigated FRPretrofitted unreinforced clay brick masonry walls. The three specimens used in this study consist of (1) reinforced concrete frame infill masonry (RCFIM), (2) confined masonry wall (CMW), and (3) wall without reinforcement/ordinary wall (W). The test results are presented in the form of graphs (Fig. 7) and the following Table 3.

This study discusses the test of partial material characteristics and the performance of the interlocking concrete block wall in line with the diagonal load direction to determine the diagonal shear strength. This diagonal shear strength test was designed on phenomena to improve a non-engineered house to withstand earthquake loads. The experience of the earthquake in Indonesia shows severe damage to the couple's wall with a pattern of damage, such as crossing diagonal lines due to the two-way earthquake load back and forth. In line with the previous researches [24-26], the wall damage occurs in-plane and out-of-plane directions of the wall. The possibility of damage of this type occurs in the walls of various types of forming material. This damage pattern can be used as a reference in repairing damaged walls of the non-engineered building after disasters [8].

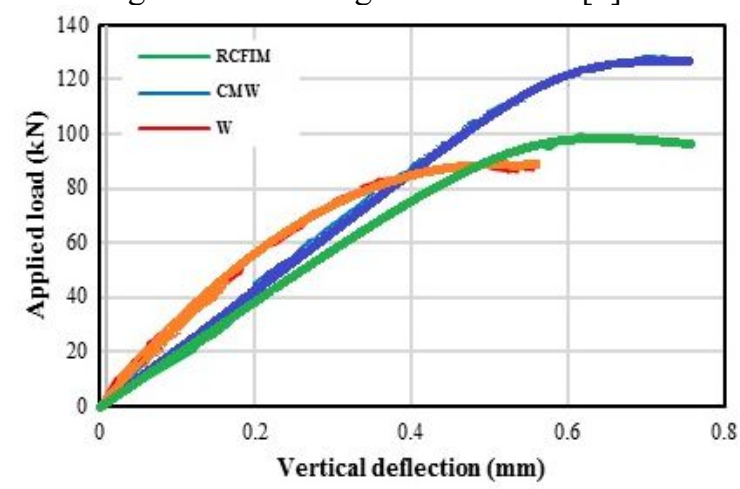

Fig. 7. Load-displacement relationships utilizing three different construction methods of the masonry wall.

Fig. 7 presents the load-displacement relationships for three different masonry walls that have been smoothed for better representation. The three walls comprise RCFIM, CMW, and W. It is clearly demonstrated in Fig. Seven that ordinary walls have no additional reinforcement except the contribution of the interlocking system between concrete blocks. Consequently, this wall provides the lowest diagonal shear strength and ductility capacity compared to the other two types of walls. The RCFIM and CMW walls confined with the $\mathrm{RC}$ frame system produce greater diagonal shear strength and vertical deflection. In between the last two walls, the CMW wall contributes to higher strength compared to the RCFIM wall, but the resulting displacement ductility is relatively the same. The wall type of CMW has greater strength due to the excellent adhesion between the interlocking concrete block and RC frame, so this type of wall is more suitable for non-engineered earthquake-resistant buildings. Conversely, for mounting walls in high-rise engineered buildings are not recommended to use this type of wall, but it is better to use RCFIM type walls.

According to the formula in the ASTM standard of E519-02-2002 [21] in calculating the diagonal shear stress on a masonry wall, the shear stress on the net area can be computed based on the applied vertical load divided by the net area of the specimen. Thus, the diagonal shear stress in the wall is directly affected by the vertical load and net area of the specimen. In this research, the interlocking and wall bracing system of the concrete block has significantly contributed to the wall strength.

Table 2 recapitulates the performance of concrete block for different construction methods on the wall systems. In line with the theoretical basis on the masonry wall, the CMW demonstrates the highest diagonal shear strength of $0.607 \mathrm{MPa}$ on average. While another two wall types produce similar results of 0.459 and $0.462 \mathrm{MPa}$ for the $\mathrm{W}$ and RCFIM wall types, respectively, but they are lesser shear stresses than the CMW wall.

In contrast, the RCFIM does not contribute significantly to the shear stress, although it has been strengthened with the RC frame confinement system. In general, the construction method of CMW is used in the practical construction of masonry walls for non- 
engineered buildings. The wall can be formed using clay brick, ordinary concrete block, or interlocking concrete block, and the experimental test of the wall can be undertaken in such a manner $[27,28]$

Table 2. Test results of the diagonal shear stress.

\begin{tabular}{|c|c|c|c|c|c|c|c|c|}
\hline \multirow[b]{2}{*}{ No } & \multirow{2}{*}{$\begin{array}{l}\text { Specimen } \\
\text { type }\end{array}$} & \multirow[b]{2}{*}{$\begin{array}{c}\operatorname{Maximum} \\
\operatorname{load}(N)\end{array}$} & \multicolumn{3}{|c|}{ Dimension (mm) } & \multirow[b]{2}{*}{$\underset{\left(\mathbf{m m}^{2}\right)}{A_{n}}$} & \multirow{2}{*}{$\begin{array}{l}\text { Shear } \\
\text { stress } \\
\text { (MPa) }\end{array}$} & \multirow{2}{*}{$\begin{array}{c}\text { Average } \\
\text { shear } \\
\text { stress } \\
\text { (MPa) }\end{array}$} \\
\hline & & & $\begin{array}{c}\text { Width } \\
\text { (w) }\end{array}$ & $\begin{array}{c}\text { Height } \\
\text { (h) }\end{array}$ & $\begin{array}{c}\text { Thickness } \\
\text { (t) }\end{array}$ & & & \\
\hline 1 & RCFIM 1 & 76773.06 & 1205 & 1205 & 113 & 136165 & 0.399 & \multirow{3}{*}{0.462} \\
\hline 2 & RCFIM 2 & 87259.95 & 1210 & 1210 & 110 & 133100 & 0.464 & \\
\hline 3 & RCFIM 3 & 100326.87 & 1208 & 1208 & 112 & 135296 & 0.524 & \\
\hline 4 & CMW 1 & 117327.60 & 1217 & 1217 & 110 & 133870 & 0.620 & \multirow{3}{*}{0.607} \\
\hline 5 & CMW 2 & 130943.88 & 1215 & 1215 & 113 & 137295 & 0.674 & \\
\hline 6 & CMW 3 & 103642.65 & 1210 & 1210 & 115 & 139150 & 0.527 & \\
\hline 7 & W 1 & 89741.88 & 1210 & 1210 & 110 & 133100 & 0.477 & \multirow{3}{*}{0.459} \\
\hline 8 & W 2 & 75330.99 & 1200 & 1200 & 113 & 135600 & 0.393 & \\
\hline 9 & W 3 & 95363.01 & 1205 & 1205 & 110 & 132550 & 0.509 & \\
\hline
\end{tabular}

Table 3. Typical crack patterns on different wall types.

\begin{tabular}{|c|c|c|c|c|}
\hline \multirow{2}{*}{$\begin{array}{l}\text { Construction } \\
\text { method }\end{array}$} & \multirow{2}{*}{ Wall type } & \multicolumn{3}{|c|}{ Specimen number } \\
\hline & & 1 & 2 & 3 \\
\hline $\begin{array}{l}\text { Reinforced } \\
\text { concrete frame }\end{array}$ & RCFIM & & & \\
\hline Confined masonry & CMW & & & \\
\hline $\begin{array}{l}\text { Wall without } \\
\text { reinforcement }\end{array}$ & W & & & \\
\hline
\end{tabular}

Table 3 summarizes the typical three-wall crack pattern at the end of the test that characterizes the sliding behavior in the wall tested in the diagonal direction. In this study, each type of wall has three specimens to represent its performance. The test results seem to confirm that after the earthquake, the masonry wall suffers crack damage that spreads out toward the diagonal of the wall. Referring to Mahmood and Ingham's research [23], the test results have demonstrated that the crack propagates vertically following the in-plane diagonal direction of the wall. It is observed that there is no out-of- plane crack damage to the wall due to the only centric load without any lateral or perpendicular load applied.

The wall types of CMW and RCFIM were confined by $\mathrm{RC}$ tie-beam and tie-column elements as a function of a simple RC frame affecting the relatively same damage patterns. The dimension of $110 \times 110(\mathrm{~mm})$ were used in the RC tie-beam and tie-column. The compressive strength of concrete was $25 \mathrm{MPa}$, and the tensile strength of steel was $300 \mathrm{MPa}$. The rebars of $4 \varnothing 10$ and Ø6-100 were utilized for the longitudinal reinforcement and confinement, respectively. Given this construction method, the crack development pattern spreads out 
progressively along with the increase of vertical deflection of the frame. This phenomenon illustrates the crack pattern makes sense with the theoretical basis of diagonal shear stress. Besides, the crack propagation was not only occurred in the mortar but also in the concrete block itself, showing that the interrelated effects of the interlocking system perfectly worked. In contrast, the wall type of $\mathrm{W}$ provides a slightly different failure mode, where the wall starts cracking, not at the corner of the wall, and propagates vertically following the loading direction.

\subsection{Compressive Strength of Concrete block Wall}

Fig. 8 presents a simple test of compressive strength on the concrete block masonry to determine the modulus of elasticity, and the test results are listed in Table 4. Referring to Table 4 , the compressive strength $\left(\mathrm{f}_{\mathrm{k}}\right.$ ') was defined as follows, $\mathrm{f}_{\mathrm{k}}{ }^{\prime}=\left(\mathrm{P}_{\mathrm{u}}+\mathrm{W}\right) /(\mathrm{B} \cdot \mathrm{b})(\mathrm{MPa})$.
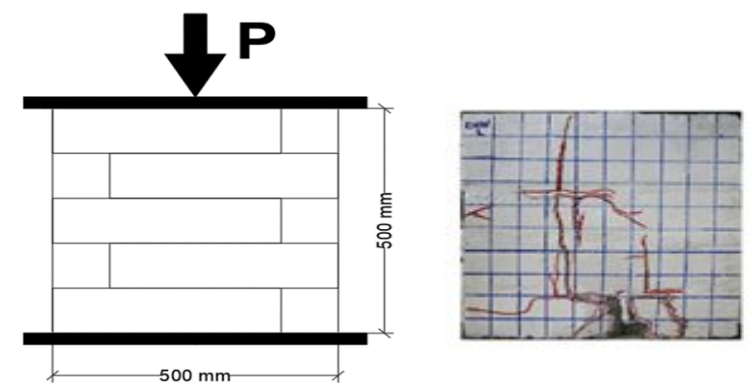

(a) Sample

(b) Crack pattern

Fig. 8. A compressive strength test of the masonry wall.

The recorded stress-strain of the concrete block is shown in Fig. 9. The modulus of elasticity of concrete block masonry is then calculated based on the second strain divided by the second strain, as depicted in Fig. 9. The second stress value is considered $40 \%$ of the maximum stress, and then the second strain value is adjusted to the stress value. The elastic modulus is written in the following equation, $\mathrm{E}=\sigma_{2} / \varepsilon_{2}(\mathrm{MPa})$. The computed modulus of elasticity $1881.112 \mathrm{MPa}$.

Table 4. The compressive strength result of the concrete block masonry wall.

\begin{tabular}{|c|c|c|}
\hline Variable & Value & Units \\
\hline $\begin{array}{c}\text { Maximum } \\
\text { loads }(\mathrm{Pu})\end{array}$ & 79294.23 & $\mathrm{~N}$ \\
\hline Width (B) & 500 & $\mathrm{~mm}$ \\
\hline Thickness (b) & 110 & $\mathrm{~mm}$ \\
\hline $\begin{array}{c}\text { Tool weight } \\
(\mathrm{W})\end{array}$ & 236.42 & $\mathrm{~N}$ \\
\hline Time & 650 & $\mathrm{sec}$ \\
\hline
\end{tabular}

\begin{tabular}{|c|c|c|}
\hline $\begin{array}{c}\text { Compressive } \\
\text { strength }\left(\mathrm{f}_{\mathrm{k}} \text { ') }\right.\end{array}$ & 1.446 & $\mathrm{MPa}$ \\
\hline $\begin{array}{c}\text { Modulus of } \\
\text { elasticity }\end{array}$ & 1881.112 & $\mathrm{MPa}$ \\
\hline
\end{tabular}

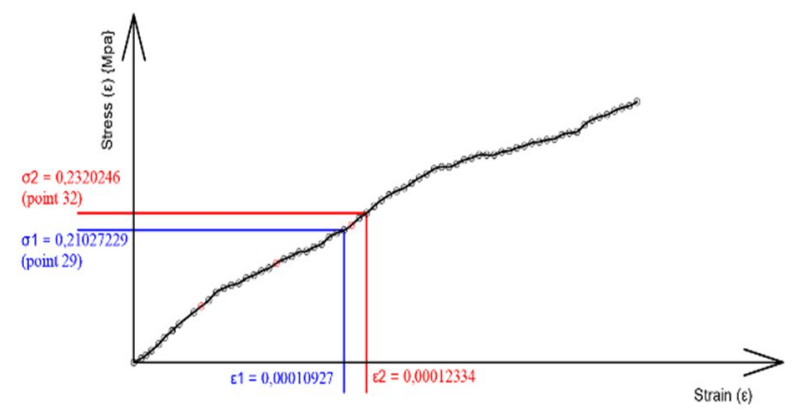

Fig. 9. The stress-strain relationship.

The results of this modulus of elasticity have been compared with similar research [4, 19]. According to Anggraeni et al. [4] and Jonaitis and Zavalis [19], the optimum values of elasticity modulus were 1248 and 1086.24 $\mathrm{MPa}$, respectively. These results are smaller compared with the modulus of elasticity of concrete blocks resulted from this research. Although, the research method used in the study is similar, however, the material and its composition are the different sources, resulting in dissimilar values of elasticity modulus.

\section{Conclusion}

Preliminary research on the experimental investigation on the interlocking concrete block for the masonry wall applied to non-engineered earthquake-resistant buildings was conducted. The research objective focuses on the compressive strength of mortar, diagonal shear stress, ductility capacity, and modulus of elasticity of the wall. Based on the results and discussion, the subsequent conclusions can be drawn as follows.

1. The ordinary mortar of $1: 5$ produces the average compressive strength of $7.24 \mathrm{MPa}$. Whereas another ratio of 1:4 provides higher average compressive strength of $8.64 \mathrm{MPa}$. In contrast, the mortar with glass powder as a partial replacement on fine aggregate, both compositions provide significant compressive strengths of 9.21 and $11.62 \mathrm{MPa}$, respectively.

2. Based on the diagonal shear test, the wall type CMW produces the highest shear stress of $0.607 \mathrm{MPa}$ compared to the other two wall types, i.e., RCFIM and $\mathrm{W}$, resulting in lesser shear stresses of 0.462 and 0.459 $\mathrm{MPa}$, respectively.

3. The CMW and RCFIM wall types give very close values at each other, and the rest of the $\mathrm{W}$ wall type has lesser ductility capacity.

4. The optimum compressive strength of the concrete block wall is $1.446 \mathrm{MPa}$ resulting in the modulus of elasticity of $1881.112 \mathrm{MPa}$.

5. The proposed interlocking models of concrete block contribute to better strength than ordinary clay bricks 
for the masonry wall, and the CMW is preferably used to install the typical masonry wall of non-engineered earthquake-resistant houses.

The authors would like to acknowledge the Directorate General of Higher Education, Ministry of Research and Technology and Higher Education, which granted a multi-year research project under the Grant Competition Scheme (2019-2020), and the Department of Civil Engineering and Disaster Risk Management, Islamic University of Indonesia, which supported utilization of all experimental devices.

\section{References}

1. Martin, J. D., Indonesia Disaster Management Reference Handbook, Center for Excellence in Disaster Management \& Humanitarian Assistance, June 2018, 89 p.

2. Arya, A. S., Boen, T., Ishiyama, I., Guideline for Earthquake Resistant Non-engineered Construction, the United Nations Educational Scientific and Cultural Organization (UNESCO), Paris, France, (2014).

3. Teguh, M., Purnomo, A.D., Satria, S.P., Karakteristik Batako-Kait Sebagai Dinding Pasangan. Prosiding Seminar Nasional Seri 7 "Menuju Masyarakat Madani dan Lestari”, Direktorat Penelitian dan Pengabdian Masyarakat, Universitas Islam Indonesia, Yogyakarta. 22 November 2017, (2017) (in Indonesian language).

4. Anggraeni, M.Y., Sudarsana, I.K., dan Sukrawa, M., J. Spektrans 3 (2) (2015)

5. Bennett, R.M.; Boyd, K.A.; Flanagan, R.D. J. Struct. Engg., 123, (1997), pp. 920-926.

6. Lourenço, P.B.; Vasconcelos, G.; Medeiros, P.; Gouveia, J., Constr. Build. Mater. 24 2317-2330 (2010)

7. Teguh, M., Int. J. of Engg Tech. Innov. 6 (2) 152-164 (2016)

8. Teguh, M., Procedia Engineering 171 191-200 (2017)

9. Anonim, Persyaratan Beton Struktural Untuk Bangunan Gedung, SNI 2847-2013, Departemen Pekerja Umum: Jakarta, (2013) (in Indonesian language).

10. Lin, Y., Biggs, D., Dist. M., Wotherspoon, L., and Ingham, J. M. J. of Struct. Engg (2014)

11. Da Porto, F.; Guidi, G.; Garbin, E.; Modena, C. J. Struct. Eng. 136 1379-1392 (2010)

12. Magenes, G.; Calvi, G.M. Earthq. Eng. Struct. Dyn., 26 1091-1112 (1997)
13. Sutrisno, W., J. Rekayasa dan Inovasi Teknik 2 (2) (2017)

14. Islam, S. G. M., Rahman, M. H., Kazi, N. Int. J. of Sustainable Built Envt 6 37-44 (2017)

15. Du, H., and Tan, K. H., J. of Advd Concrete Tech. 12 468-477 (2014)

16. Rahma, A., Naber, N. E., and Ismail, S. I., Cogent Engg J. (2017)

17. Elaqra, H. A., AbouHaloub, M. A., and Rustom, R. N., Const and Builg Mat. J. 203 (2019)

18. EN 1015-11:2007 Methods of Test for Mortar for Masonry. Part 11-Determination of Flexural and Compressive Strength of Hardened Mortars; CEN (European Committee for Standardization): Bruxelles, Belgium, (1999).

19. Jonaitis, B., and Zavalis, R., $11^{\text {th }}$ International Conference on Modern Building Materials, Structures and Techniques, MBMST, Elsevier, Lithuania, December 473 - 478 (2013)

20. Sorrentino, L.; Cattari, S.; Da Porto, F.; Magenes, G.; Penna, Bull. Earthq. Eng.1-25 (2018)

21. American Society for Testing and Materials, Standard Test Method for Diagonal Tension (Shear) in Masonry Assemblages, ASTM designation: E 51902, USA, (2002).

22. Pranata, Y.A., and Elvira, L., J. of Civil Engg. 12. (3), 161-172 (2013)

23. Mahmood, H.; Ingham, J.M. Diagonal Compression Testing of FRP-Retrofitted Unreinforced Clay Brick Masonry Wallettes. J. Compos. Constr. 15, (2011), pp. 810-820.

24. Willis, C.; Seracino, R.; Griffith, M. Eng. Struct. 32, 547-555 (2010)

25. Sisti, R.; Di Ludovico, M.; Borri, A.; Prota, A., Bull. Earthq. Eng. 1-21 (2018)

26. Gabor, A.; Ferrier, E.; Jacquelin, E.; Hamelin, P. Build. Mater. 20 308-321 (2006)

27. Turnšek, V.; Cacovic, F. Proc. of the 2nd Int. Brick Masonry Conf., Stoke-on-Trent, UK, 12-15 April, (1970)

28. ASTM International. ASTM D638-14, Standard Test Method for Tensile Properties of Plastics; ASTM International: West Conshohocken, PA, USA, (2014)

29. Corradi, M., Castori, G., Sisti, R., Borri, A., and Pesce, G. L., Materials 12, (2019)

30. Calderón, S., Vargas, L., Sandoval, C., and ArayaLetelier, G., $10^{\text {th }}$ International Masonry Conference, Milan, Italy, July 9-11, (2018) 